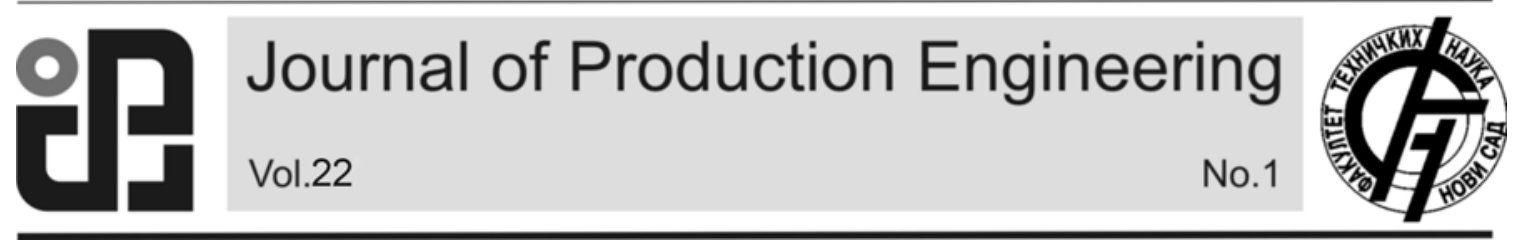

JPE (2019) Vol.22 (1)

Original Scientific Paper

Oluwole, O.I., Samuel, T.A., Adeolu, A.A., Mathew, O.A., Emmanuel, A.O.

\title{
DESIGN AND FABRICATION OF WASTE PAPER RECYCLING MACHINE FOR LABORATORY AND MEDIUM SCALE OPERATION
}

Received: 09 January 2019 / Accepted: 29 March 2019

\begin{abstract}
The current work report the design and fabrication of waste paper recycling machine that is efficient in tackling the challenges of waste paper disposal. The traditional methods of disposing waste papers have proven to be relatively expensive and unhealthy in many developing nations across the globe. Therefore, provision of low technological and cost effective machine for the recycling of these biodegradable wastes in more economical, healthy and safe for the environment is needed. Thus, the objective of this work was to design and fabricate a motorized waste paper recycling machine with slight modifications on the existing ones. The machine was designed to use rotary blades rotated by high speed electric motor followed by performance evaluation of the machine to determine its efficiency. Design calculations were used to ensure cost reliability and minimum energy consumption of the machine. The results showed that $25-30 \mathrm{~kg}$ of waste papers per hour were recycled and turned into pulp at a machine speed of $1440 \mathrm{rpm}$ which implies high and good efficiency. The pulp was used for production of waste paper based composite samples with the addition of suitable binders.
\end{abstract}

Key words: design, fabrication, waste papers, recycling machine, pulp, laboratory, medium scale.

Projektovanje i izrada mašine za reciklažu otpadnog papira za laboratorijski rad i pogon srednjih dimenzija. Sadašnji rad izveštava o dizajniranju i proizvodnji mašine za reciklažu otpadnog papira koja je efikasna u rešavanju izazova odlaganja otpadnog papira. Tradicionalne metode uklanjanja otpadnih papira pokazale su se relativno skupim i nezdravim u mnogim zemljama u razvoju širom sveta. Stoga je potrebno obezbediti nisko-tehnološku $i$ ekonomičnu mašinu za recikliranje ovih biorazgradivih otpada u ekonomičniji, zdraviji $i$ sigurniji za životnu sredinu. Stoga je cilj ovog rada bio da se osmisle i proizvedu mašine za reciklažu motornog otpada, sa malim modifikacijama na postojećim. Mašina je dizajnirana da koristi rotacione lopatice koje rotira elektromotor velike brzine, nakon čega sledi procena performansi mašine da bi se odredila njegova efikasnost. Proračuni dizajna korišteni su kako bi se osigurala troškovna pouzdanost i minimalna potrošnja energije stroja. Rezultati su pokazali da je 25-30 kg otpadnog papira na sat reciklirano i pretvoreno u pulpu pri brzini motora od 1440 o/min što podrazumeva visoku i dobru efikasnost. Pulpa je korišćena za proizvodnju kompozitnih uzoraka na bazi papirnog papira sa dodatkom pogodnih veziva.

Ključne reči: dizajn, izrada, otpadni papir, mašina za reciklažu, pulpa, laboratorijski, srednji.

\section{INTRODUCTION}

Recently, material scientists are no more interested in developing materials for targeted applications only but are also interested in their mode of disposal after use. These trends have led to the quest for more technological advancement in achieving value for what would have remained waste or ensure biodegradability after use [1]. Over the centuries, paper has been made from a wide variety of materials such as cotton, wheat straw, sugar cane waste, flax, bamboo, wood, linen rags, and hemp. Regardless of the source, fiber is needed to make paper. Today fiber comes mainly from two sources which are wood and recycled paper products [2]. Paper production is becoming popular both for house hold and for industrial purposes. As a result of this, the amount of waste generated from paper production is becoming a subject of concern. This is because wastes from paper production are biodegradable [3] and, hence, means of removing the waste from causing certain pollution to the environment is very important. The only solution therefore, is to gather these wastes for recycling purpose. Recycling process reduces the diffusion of waste by feeding them back into the economy [4]. Recycling of paper also decreases the demand for virgin pulp and, thus, reduces the overall amount of air and water pollution associated with paper manufacture and usage [5]. The nation recycling rate of some advanced countries (USA and Mexico) experienced remarkable growth from 9\% in 1989 to $28 \%$ in 1996 [6]. These wastes are sometimes used as a combustion aid for burning other organic refuse, and this liberates toxic vapours or gases that pollute the air and causes inconveniences to residents living near the landfill sights. Their values as reclaimed or recycled waste is considerably higher than their values as energy source [7]. Recycling of wastes papers is rapidly developing in almost every society and this is largely based on the environmental awareness, need to conserve materials and energy, and growing demand to increase production economy [8-9]. This, therefore, cause many private industries and few government agencies to be involved in recycling processes. Waste paper being a non-hazardous industrial waste that is highly consumed on daily basis worldwide, there is need to promote how it can be recycle with ease globally. The technology 
needs to be readily available for the global community for ecological safety. The subject of design and fabrication is the creation of new and improved machine compared to the existing ones. Such machine will aim at delivering more economically considering the overall cost of production and operation. Thus, the objective of this work is to design and fabricate paper pulp production machine using waste papers as the major raw material.

\section{CRITERIA FOR MATERIAL SELECTION AND MACHINE COMPONENTS}

The fabrication of the components/parts of the paper pulping/recycling machine was aimed at reducing human (operator) effort, processing time as well as cost of production using suitable engineering materials without compromising the efficiency of the machine. To this end, the following key criteria were considered for materials selection;
Primary consideration was given to materials that are readily availability with documented fabrication and service performance.

$>$ Minimum number of different materials were selected and used based on costs, compatibility and availability of relevant spare parts.

$>$ Operating/Service conditions.

Hopper: The inlet/hopper, which determines the quantity of waste papers to be charged, is made of stainless steel plate based on its ability to withstand working stress, thermal conductivity and good corrosion resistance.

Blades: Both the triangular and rectangular blades are made of spring steel for its good wear and corrosion resistance.

Electric Motor: A $3 \mathrm{KW}$ electric motor is the power source and mover of the machine through shaft and belt drive. The speed of the electric motor is controlled by the arrangement of the pulleys.

The assembly of the machine was achieved from fabricated parts/components of the machine via several joining processes like welding and the use of fasteners.

\begin{tabular}{|c|c|c|}
\hline $\mathrm{S} / \mathrm{N}$ & Components/Part Name & Description \\
\hline 1. & Inlet/Hopper & $\begin{array}{l}\text { Mixing chamber which is in form of a cylinder and cone. The cone is } \\
\text { truncated at a section which serves as the pulp outlet. }\end{array}$ \\
\hline 2. & Flange & $\begin{array}{l}\text { Houses the upper and lower bearings which were fastened to the } \\
\text { hopper to provide a channel for the machine shaft. }\end{array}$ \\
\hline 3. & Machine shaft & $\begin{array}{l}\text { Holds the cutting blades at right angles to each other with a distance } \\
\text { of } 50 \mathrm{~mm} \text { apart. }\end{array}$ \\
\hline 4. & Frames & $\begin{array}{l}\text { Top frame is designed to carry the entire machine components while } \\
\text { the base frame provides rigid support to reduce excessive vibrations. }\end{array}$ \\
\hline 5. & Belt and Pulleys & These serves as the transmission systems. \\
\hline 6. & Electric motor & The power source and mover of the machine through shaft and belt. \\
\hline
\end{tabular}

Table 1. Components/units of the waste paper recycling machine

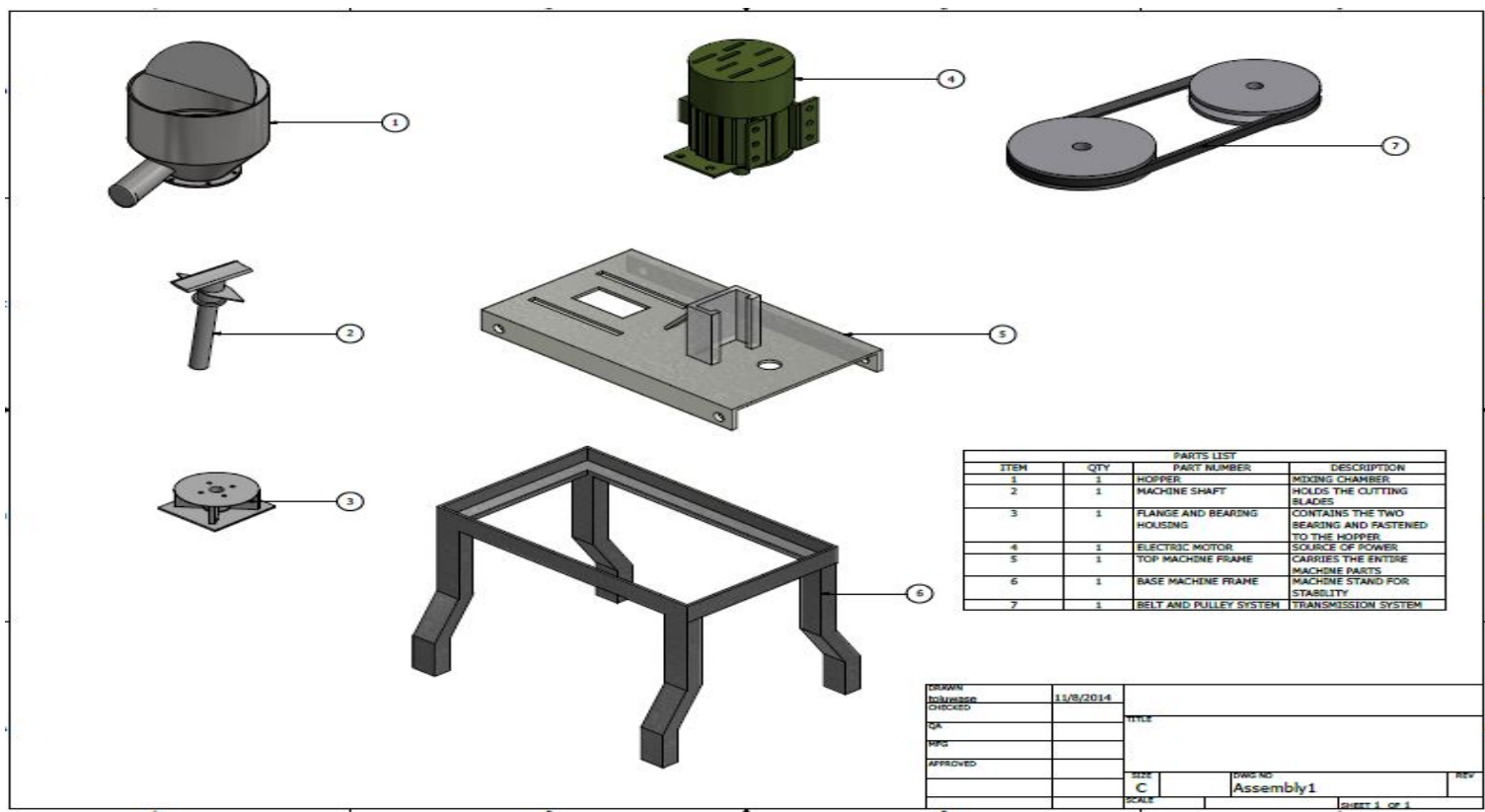

Fig. 1. Assembly drawing of the machine (exploded view) 


\subsection{Design theory and calculations}

During the design process of the machine, there are considerations for manufacturability, cost reliability, minimum energy requirement and use of local content materials for the design product [10].

\subsubsection{Inlet/Hopper design}

The hopper is in form of a cylinder and cone, with a side of the cone truncated to give the pulp outlet as shown in Fig. 2. The size was determined by using the formula for calculating volume of cylinder and cone, $\mathrm{V}_{1}$ and $V_{2}$, as given in Equation 1 to 2 while $V_{3}$ gives the final volume of the hopper as shown in equation 3 according to Daramola et al. [11].

$$
\begin{aligned}
& V_{1}=\pi \cdot r^{2} \cdot h \\
& V_{2}=\frac{1}{3} \cdot r^{2} \cdot h \\
& \mathrm{~V}_{3}=\mathrm{V}_{1}+\mathrm{V}_{2}
\end{aligned}
$$

Where; $r$ is the radius of the hopper and $h$ is the height of the hopper. The hopper wall thickness, $t$, is $6 \mathrm{~mm}$, while the height is $410 \mathrm{~mm}$ and the diameter, $\mathrm{D}$, is 310 $\mathrm{mm}$. The value $t / D$ for the hopper is less than 0.05 , which shows that it is a thinned wall, and thus, need to be reinforced with flat bars to increase its ability in order to withstand any form of pressure.

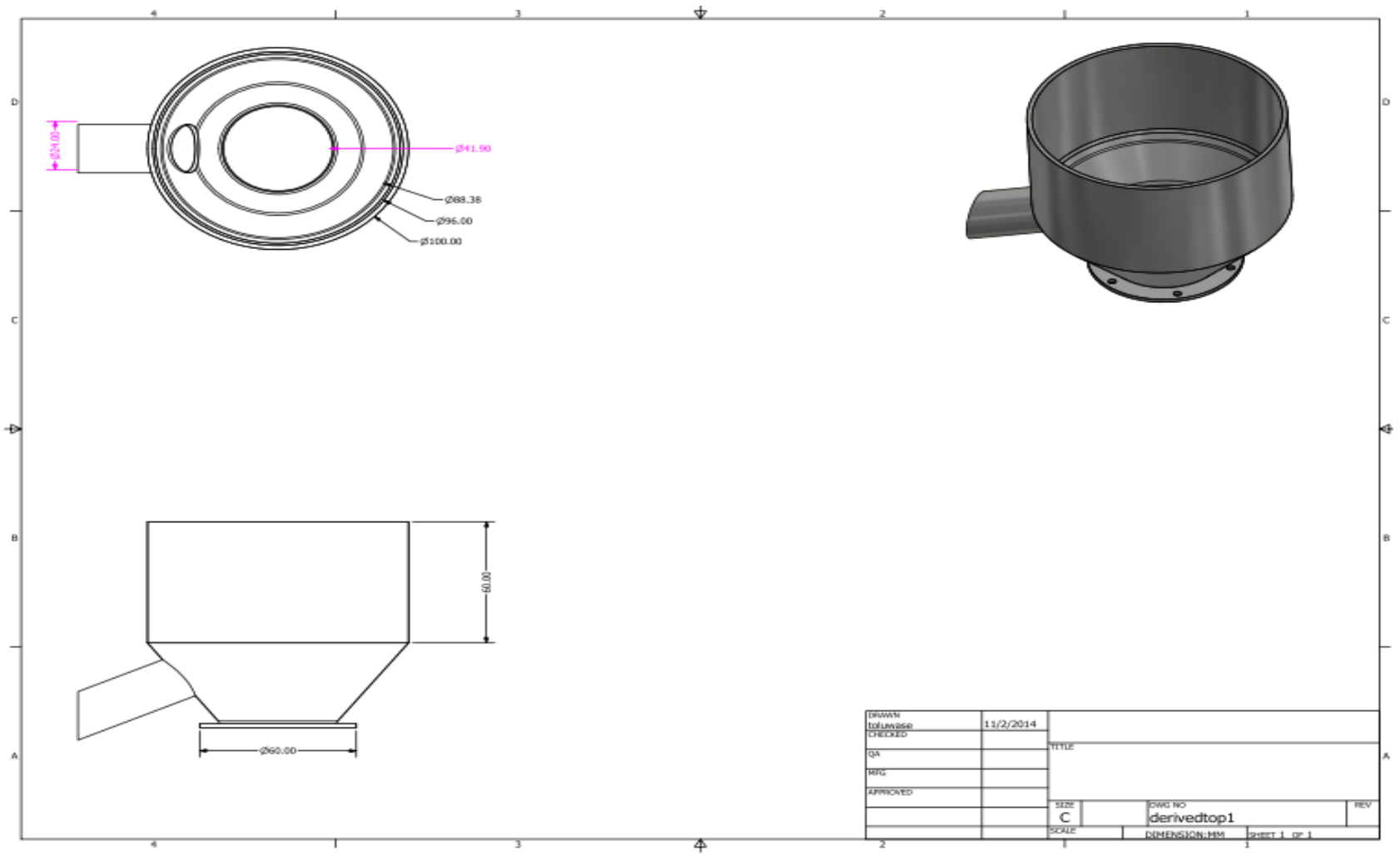

Fig. 2. Detailed design of the Inlet/Hopper, all dimensions in mm.

\subsubsection{Shaft design}

The shaft is the rotating member having a circular cross section much smaller in diameter than the shaft length. Energy transmitting elements such as pulley, belts and bearings are attached to the shaft. The loading on the shaft can be various combinations of bending (almost always fluctuating), shock or axial, normal, or transverse shear. Thus, shaft design primarily involves the determination of the correct shaft diameter to ensure adequate strength and rigidity when the shaft is transmitting power under various operating and loading conditions. Strength, using yield or fatigue (or both) as a criterion; deflection; or the dynamics established by the critical speed are also considered in designing shaft [10]. The dimension of the shaft is:

$$
>\text { Length }-460 \mathrm{~mm}
$$$$
>\text { Diameter }-50 \mathrm{~mm}
$$

These therefore, represent a simply supported beam with concentrated loads span over the length of the shaft. The resultant internal moment, $M_{X}$, at any section along the shaft may be expressed as:

$$
M_{X}=\left({M_{X Y}}^{2}+M_{x z}^{2}\right)^{1 / 2}
$$

Where; $\mathrm{M}_{\mathrm{XY}}$ and $\mathrm{M}_{\mathrm{XZ}}$ are the bending moments in $\mathrm{x}-\mathrm{y}$ and $x-z$ planes, respectively. The force exerted on a shaft in the transverse direction (perpendicular to the shaft axis) produces a maximum stress of:

$$
\begin{gathered}
\sigma b=\frac{M_{b} r}{l} \\
\tau x y=\frac{M_{t} r}{l}
\end{gathered}
$$

For a circular cross section, where $r=\frac{d}{2}, I=\frac{\pi d^{4}}{64}$ and $J=\frac{\pi d^{4}}{32}$, the bending stress according to Ismail et al, [13],

will be given as: $\sigma_{x}=\frac{32 M_{b}}{\pi d^{3}}$

For torsional stress, the expression is:

$$
\tau_{x y}=\frac{16 M_{t}}{\pi d^{3}}
$$


For a solid shaft combining torsion and bending loads by applying the maximum shear equation modified by introducing shock, fatigue and column factors, the ASME code equation is given as:

$$
d^{3}=\frac{16}{\pi \cdot \sigma \cdot s\left[\sqrt{\left(K_{b} M_{b}\right)^{2}+\left(K_{t} M_{t}\right)^{2}}\right]}
$$

Where; $\tau_{\mathrm{xy}}$-torsional shear stress $\left(\mathrm{N} / \mathrm{m}^{2}\right)$; Mt - torsional moment $(\mathrm{Nm})$; $\mathrm{Mb}$ - bending moment $(\mathrm{Nm})$; $\mathrm{Kb}$ combined shock and fatigue factor applied to bending moment; Kt - combined shock and fatigue factor applied to torsional moment; $\sigma_{b}$-bending stress; $\sigma_{s}$ allowable stress; d - shaft diameter (m)

\subsubsection{Blades Design}

The machine was designed to use rotary blades as shown in Fig. 3. These blades were sharpened for effective cutting/grinding of the waste papers. Two pieces of equilateral triangular rotary blades with a brazed rectangular blade were welded to the shaft. The rectangular blade is welded to the top of the shaft forming a T-brazed on the machine shaft which is inserted into the bore of the flange. The blades are welded at a distance of $50 \mathrm{~mm}$ apart, giving a minimum clearance for the recycling of the waste paper. The choice of other components such as bearing and belt depends on the diameter of the shaft and/or its pulley while volume of the hopper, power required by the machine as well as the required speed rate of the machine was used for the selection of the electric motor.

\section{Design of belt and pulley \\ Belt design considerations}

The V-belt 'class C' type is used for the drive of the machine, because of the advantages associated with the V-belt drive which include;

1. It can be easily installed and removed.

2. The operation of the belt and pulley is quiet.

3. It is endless and, hence, the drive is smooth as it eliminates joints.

4. It is more dependable than belt of other sections.

5. The drive is positive, because the slip between the belt and the pulley groove is negligible.

\begin{tabular}{ll}
\hline Description & Data $(\mathbf{m m})$ \\
\hline Type & v-belt \\
Thickness & 8.0 \\
Top width & 12.5 \\
Bottom width & 7.2 \\
\hline
\end{tabular}

Table 2. Belt drive description

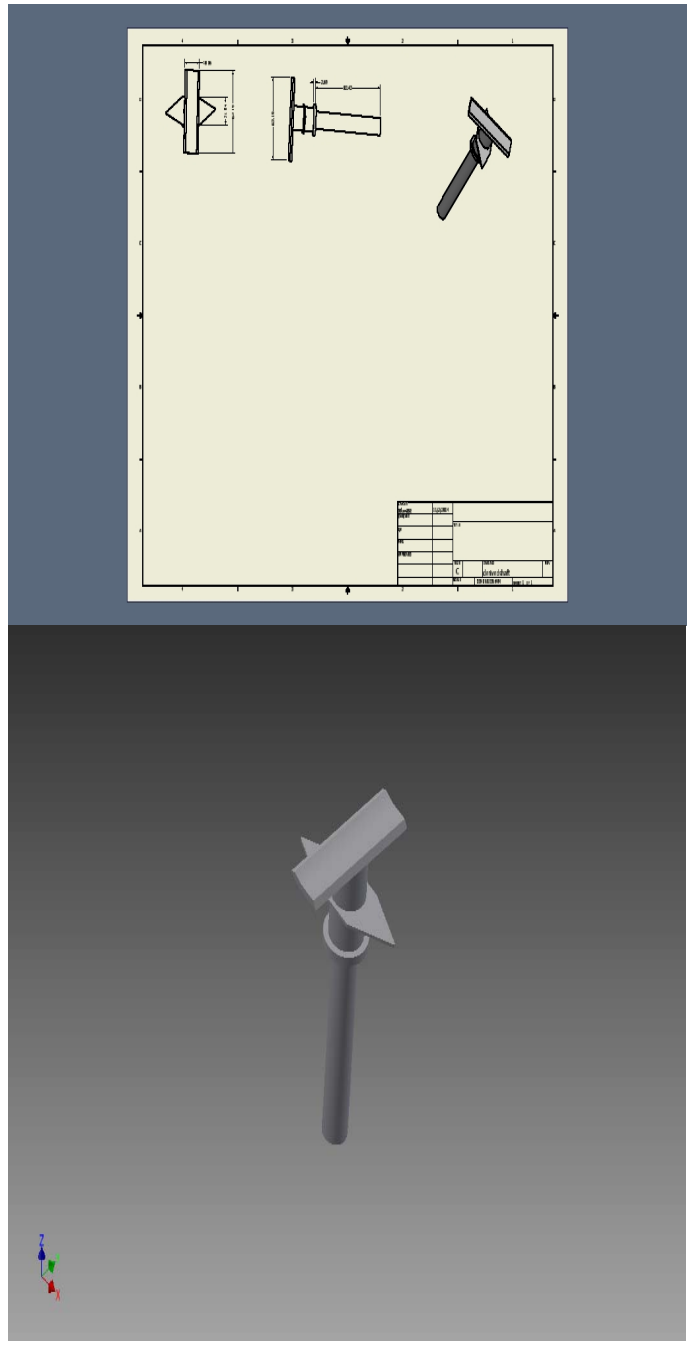

Fig. 3. Shaft design showing the positions of the rotary blades.

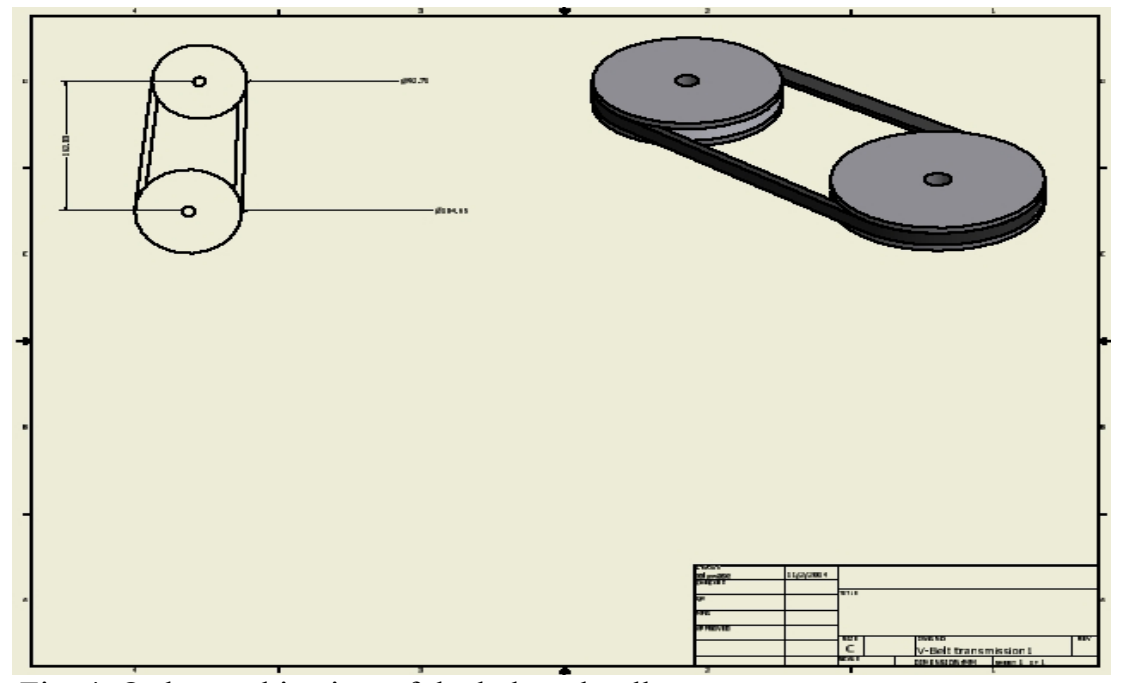

Fig. 4. Orthographic view of the belt and pulley system. 


\section{2 Determination of speed ratio}

Speed ratio is given as; $\frac{N_{1}}{N_{2}}=\frac{D_{2}}{D_{1}}$

Where; $\mathrm{N}_{1}$ - Speed of the driver pulley; $\mathrm{N}_{2}$ - Speed of the driven pulley; $\mathrm{D}_{1}$ - Diameter of the driver pulley; $\mathrm{D}_{2}$ Diameter of the driven pulley

Therefore, speed of the driven pulley is;

$N_{2}=\frac{N_{1} D_{1}}{D_{2}} ; N_{2}=\frac{1440 \times 125}{185}=\frac{180000}{185}=973 \mathrm{rpm}(11)$

\subsection{Determination of belt speed}

The speed of the belt was determined from the expression given by Khurmi and Gupta [14] as:

$$
V=\frac{\pi \cdot N_{1} D_{1}}{60}
$$

Where; $\mathrm{N}_{1}$ and $\mathrm{D}_{1}$ are the speed and diameter of the driver pulley, respectively,

$\mathrm{N}_{1}=1440 \mathrm{rpm}, \mathrm{D}_{1}=125 \mathrm{~mm}=0.125 \mathrm{~m}$

$V=\frac{\pi \times 1440 \times 0.125}{60}=9.43 \mathrm{~m} / \mathrm{s}$

Therefore, speed of the belt, $\mathrm{V}=9.43 \mathrm{~m} / \mathrm{s}$

\subsection{Determination of belt tension}

The tension in the belt was determined using the following;

Length of an open belt is given as;

$L=\frac{\pi}{2}\left(D_{1}+D_{2}\right)+2 \cdot C+\frac{\left(D_{1}+D_{2}\right)^{2}}{4 C}$

Where; $D_{1}$ is diameter of the driver pulley $(\mathrm{mm}), \mathrm{D}_{2}$ is diameter of the driven pulley $(\mathrm{mm}), \mathrm{C}$ is center distance between the two pulleys ( $\mathrm{mm}$ ) as stated by Akinnuli et al. [15]

Tension on the tight side of the belt is given as;

$$
\begin{aligned}
& T_{1}=T-T_{c} \\
& T=a \times A \\
& T_{c}=M \cdot v^{2}
\end{aligned}
$$

Where; $\mathrm{T}_{1}$-Belt tension on the tight side $(\mathrm{N}), \mathrm{T}$ Maximum tension in the belt $(\mathrm{N}), \mathrm{T}_{\mathrm{c}}$ - Centrifugal tension $(\mathrm{N}), \alpha-$ Angle of wrap of the belt, A - Cross sectional Area of the V-belt $\left(\mathrm{mm}^{2}\right)$, M - Mass of the Vbelt $(\mathrm{kg})$ and $\mathrm{v}$ - Linear velocity $\left(\mathrm{m} / \mathrm{s}^{2}\right)$

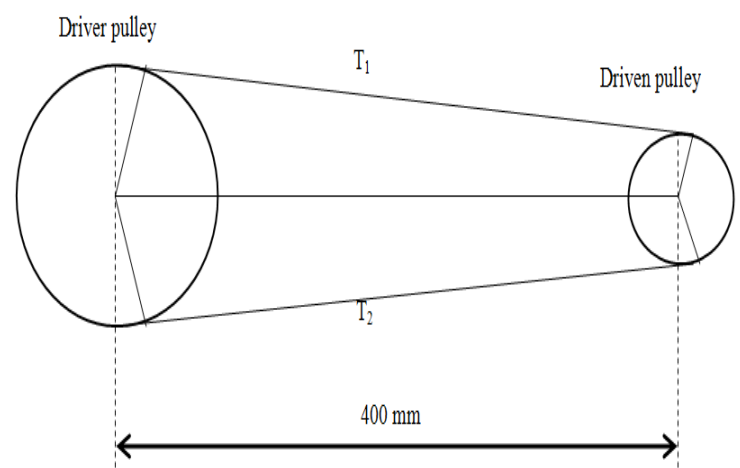

Fig. 4. Design of belt and pulley

Tension on the slack side of the belt is obtained from;

$$
2.3 \log \left(\frac{T_{1}}{T_{2}}\right)=\mu \theta
$$

$$
\theta=\frac{(180-2 a) \pi}{180}
$$

Where; $\mathrm{T}_{2}-$ Belt tension on the slack side $(\mathrm{N}), \mu$ coefficient of friction and $\theta$ - Angle of lap on the small pulley (rad) according to Daramola et al. [11].

Torque on the shaft of the driven pulley is given as;

$$
T_{L}=\frac{\left(T_{1}-T_{2}\right) D_{2}}{2}
$$

Power transmitted;

$$
P=\left(T_{1}-T_{2}\right) V
$$

Total power required is calculated thus;

$$
P_{T}=5 v\left(W_{1}+W_{2}\right)
$$

Where; $\mathrm{W}_{1}$ - weight of the pulley $(\mathrm{N}), \mathrm{W}_{2}$ - weight of the shaft $(\mathrm{N})$ and $\mathrm{v}$ - Linear velocity $\left(\mathrm{m} / \mathrm{s}^{2}\right)$

\section{ASSEMBLING OF FABRICATED PARTS}

Fig. 5 shows the diagram of the recycling machine after components design, materials selection, fabrication and assembling. The processes involved are listed:

$>$ Measuring, marking out and cutting of the various parts of the mild steel

$>$ Bolts, nuts and stud machining

$>$ Drilling/Holes formation

$>$ Welding/Joining of machined parts

$>$ Finishing and painting for aesthetics

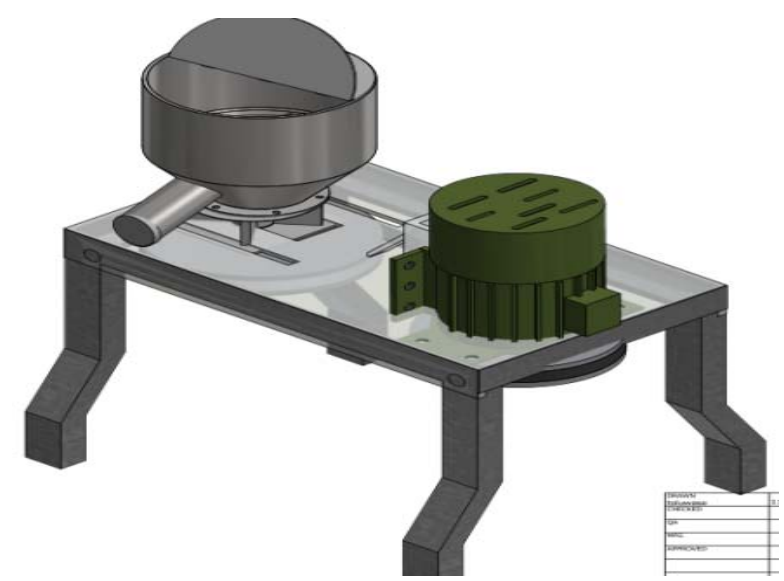

Fig. 5. Waste paper Pulping/Recycling Machine showing Belt and Pulley as hidden details

\section{DETERMINATION OF THE MACHINE EFFICIENCY}

After fabrication and assembling of the various components of the machine, performance evaluation was carried out to determine the efficiency of the machine through the production of waste paper pulp based composite samples from the recycled/pulped waste papers.

\section{Working Principle;}

- A known weight of the waste papers were collected and soaked in water prior to charging into the machine.

- The soaked waste paper was charged into the machine and grinded for 8-10 minutes.

- The grinded waste paper in slurry form is discharged through the pulp outlet as shown in Fig. 6. 


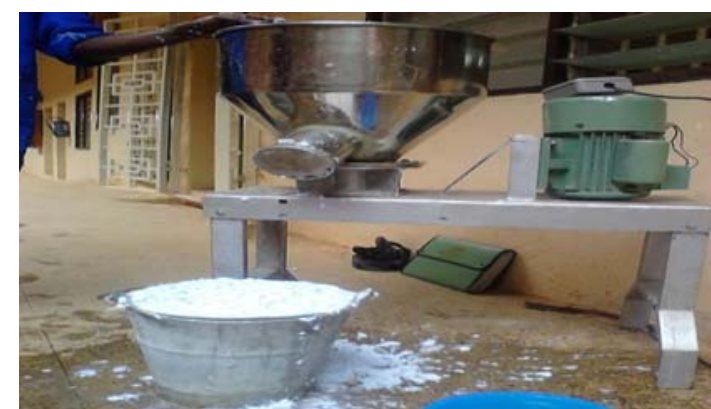

Fig. 6. Pulped Waste Paper

The efficiency of the machine per hour was determined after considering the amount in kilograms that the machine grinded in a record time. The result showed that $25-30 \mathrm{~kg}$ of waste papers per hour were recycled and turned into pulp at a machine speed of $1440 \mathrm{rpm}$ which implies high and good efficiency. The product obtained after pulping the waste paper by the machine was in form of thick slurry containing water that was added for the recycling operation. The pulp was used for production of waste paper based composite samples with the addition of suitable binders. The evaluated results were in agreement with the work by Oladele and Afolabi [16]. Also, the machine was used in the production of waste paper pulp for the development of composite samples in the work titled; Flexural, water absorption and wear responses of green composites from bio-resources by Oladele et al., [17]. The machine has proven to be efficient in turning waste paper to pulp at the most convenient level of operation.

\section{CONCLUSIONS}

Simple and easy to operate waste paper pulping machine that can be regarded as low technology equipment needed for research and development has been fabricated. The waste paper recycling machine was of about $25-30 \mathrm{~kg}$ working capacity per hour. The machine was design to work as laboratory as well as medium scale production equipment. The pulp can be used for the production of paper board samples and various composites. The machine will assist in cleaning up our environment of biodegradable wastes, which have constituted a serious health and environmental problems in our society.

\section{REFERENCES}

[1] Oladele, I.O. 2013. Development of Sisal Fibre Reinforced Polypropylene Composites Suitablefor Structural Applications, PhD Thesis Submitted to the Department of Metallurgical and Materials Engineering, Federal University of Technology, Akure, Nigeria.

[2] http://americanrecyclingca.com/2011/03/paper/paper -making-and-recycling/ retrieved $9^{\text {th }}$ May, 2017.

[3] Anna T. 2008. Pulp and Paper Pollution: The Toxic Story of Federal Neglect, Reach for Unbleached Foundation, Comox, 62-64.

[4] http://www.un.org/esa/NationalReports/WasteMana gement.pdf retrieved $21^{\text {st }}$ July, 2017.

[5] Jeffries, T. 1997. Kraft pulping: Energy consumption and production, University of Wisconsin, Biotech Center 110-117.

[6] Sonnenfeld, D.A. 2002. Social Movements and Ecological Modernization: the Transformation of Pulp and Paper Manufacturing, Development and Change, 33(1), 1-27.

[7] Andrew, G.D., Subramman, A. 1992. Emerging Technologies in Plastics Recycling, Washington, D.C. USA, ACS Symposium Series, 513.

[8] Chatterjee,S., Kumar, K. 2009.Effective Electronic Waste Management and Recycling Process Involving Formal and Non-Formal Sectors, International Journal of Physical Sciences, 4 (13), 893-905.

[9] La Mantia, F.P. 1993. Recycling of Plastics Materials, $1^{\text {st }}$ Edition, New York, Chemical Technology Publishing Inc.

[10] Olayanju, T.M.A, Okonkwo, C.E, Ojediran, J.O, Alake, S.A, Okunola, A.A, Alhassan, E.A, Olaniran, A, Idahosa, E.O. 2018. Development of an improved gari fryer, International Journal of Mechanical Engineering and Technology, 9(11)769778.

[11] Daramola, O.O., Oladele, I.O., Adediran, A.A., Babarinsa, S.O. 2017. Design of a laboratory polyurethane foam recycling machine, Journal for Technology of Plasticity, 42(2), 47-57.

[12] Hamrock, B.J., Jacobson, B., Schmid, S.V. 1999. Fundamentals of Machine Elements, $1^{\text {st }}$ Edition, McGraw-Hill Inc., New York.

[13] Ismail S.O., Ojolo S. J. Orisaleye J.I., Adediran A.A., Fajuyitan O.O. 2015. Design and Development of an Improved Palm Kernel Shelling and Sorting Machine. European International Journal of Science and Technology, 4(2), 225-240.

[14] Khurmi, R. S., \& Gupta, J. K. 2006. A Textbook of machine design. (14th ed.). New Delhi: S. Chand, (Chapter 9).

[15] Akinnuli, B.O., Osueke, C.O.,Ikubanni, P.P., Agboola, O.O., Adediran, A.A. 2015. Design Concepts Towards Electric Powered Gari Frying Machine, International Journal of Scientific \& Engineering Research, 6(5), 1043-1050.

[16] Oladele, I.O., Afolabi, I.S. 2015. Development of paper pulp filled cementitious composites for furniture and fittings applications, Acta Tehnica Corviniensis - Bulletin of Engineering, 4, 73-78.

[17] Oladele, I. O., Abegunde, O. O. Masud, A. O. 2018. Flexural, water absorption and wear responses of green composites from bio-resources. African Journal of Science, Technology, Innovation and Development, 10(7), 1-6.

Authors: ${ }^{* 1} \mathrm{Dr}$ Oladele Isiaka Oluwole, ${ }^{1}$ Taiwo Anuoluwapo Samuel, ${ }^{2}$ Adediran Adesoji Adeolu, ${ }^{1}$ Omoniyi Ayodeji Mathew, ${ }^{1}$ Adanri Oluwafemi Emmanuel. ${ }^{1}$ Department of Metallurgical and Materials Engineering, Federal University of Technology, Akure, PMB 704, Ondo State, Nigeria. ${ }^{2}$ Department of Mechanical Engineering, Landmark University, OmuAran, PMB 1001, Kwara State, Nigeria. Email: wolesuccess2000@yahoo.com, adediran.adeolu@lmu.edu.ng 